\section{Eastern promise unfulfilled}

\section{Tokyo}

ON the brink of a showdown over trade week reached an agreement intended to increase sales of US supercomputers to Japan's universities and public research institutes. But although the new agreement may help diffuse trade tension between the two countries it is unlikely to have much effect on the actual number of US supercomputers sold in Japan.

The reluctance of Japan research institutes to buy US supercomputers has long been a cause a frustration in the US Congress. The US manufacturer Cray Research Incorporated dominates the world market but has only managed to sell two supercomputers to Japan's public sector. Nearly all government-financed purchases have gone to Japanese manufacturers such as NEC and Fujitsu.

In 1987 Japan agreed to make government procurement of computers more open, but so far this has not led to any new sales for Cray. Last year, supercomputers were listed as an item for possible trade retaliation under the US Omnibus Trade the new agreement, worked out by trade negotiators in Washington last week, Japan has agreed to discourage "academic discounting", a practice whereby Japanese manufacturers sell supercomputers to public institutions at rock-bottom prices. issues, the United States and Japan last and Competition Act of 1988. But under
The discounts, often as much as 80 per cent of normal retail price, have effectively shut Cray out of the market. And government ministries have encouraged the practice by giving public institutions sufficient funds to buy supercomputers only at the highly discounted prices.

Government ministries will now allot bigger budgets for supercomputers, and will take into account performance as well as price when selecting computers. US and Japanese government officials welcomed the accord; failure to reach an agreement could have led to punitive trade tarrifs against Japan under the Omnibus Act.

But the new agreement is unlikely to boost US supercomputer sales. Government ministries have increased their budgets for purchasing individual supercomputers simply by decreasing the total number of supercomputers which will be bought. In fiscal 1990, for example, government ministries will buy four supercomputers instead of the ten originally planned. And although Japan has promised to eliminate academic discounts, Japanese manufacturers have already reduced the retail price of their supercomputers, so making the discounts look smaller. As an official of Cray's Japanese subsidiary commented "the agreement in Washington is all very well but we will wait to see the results".

David Swinbanks
Have the starfish gone for good?

\section{Sydney}

REPORTS that the Great Barrier Reef off Australia has survived the latest outbreak of Crown-of-Thorns starfish and is on the mend are premature, marine biologists here say. A survey, carried out by the Australian Institute of Marine Sciences (AIMS) between November last year and January, reported significant reductions in the numbers of Crown-of-Thorn starfish (Acanthaster planci) between Lizard Island and Innisfail, in the centre third of the reef. On one of the worst-hit reefs, off Green Island, an estimated 1.5 million starfish during the height of the outbreak in 1980 reduced coral cover by 20 per cent over five years. The AIMS survey reported noticeable regrowth in the area.

But despite widespread press reports that the reef is no longer under threat, the AIMS survey reported reduction in starfish numbers only in the central third of the reef, between Cooktown and Townsville.

On Old Reef, near Townsville, seven starfish were reported in 1985, 11 in 1986, 3,266 in $1987,1,000$ in 1988 and only two in 1989. However, south of Townsville there are increasing reports of outbreaks of starfish. In 1985 only 5 per cent of the reefs in this area reported infestations. Four years later there were outbreaks on $\mathbf{4 0}$ per cent of the reefs.

What happens to the starfish once they have run out of food is a mystery. There is no evidence of mass mortality and there has been little research so far into the movement of larvae, believed to be the source of the outbreaks further south.

It seems to take $\mathbf{1 5}$ years for reefs to recover from Crown-of-Thorns infestations, although slow-growing corals can take up to 100 years to recuperate. The cause of such outbreaks is still unknown and continues to be a subject of debate between those who think the infestations are man-made, with overfishing removing the natural predators of the starfish, and those who believe the outbreaks to be a natural phenomenon.

Tania Ewing into three separate companies, one to handle local services, one for longdistance telecommunications, and a third for mobile telecommunications, such as car telephones (see Nature 341, 474; 1989).

The council's plan is intended to promote competition but there is strong opposition to the council's proposals in government, industry and political circles.

The recommendation to break up NTT comes on the heels of a review of NTT by the Management and Coordination Agency that calls on the company to reduce its staff and allow fairer competition with newcomers in the telecommunications market.

Three new domestic telecommunications companies, Teleway Japan Ltd,
Japan Telecom Company and DainiDenden Inc., have welcomed the council's me new compa compete with NTT in the long-distanc market but have to use NTT lines for local connections. As a result, NTT still controls 98 per cent of the market and longdistance charges in Japan remain very high compared with those in other developed nations.

NTT management and unions are united in their opposition to the calls for its break-up. NTT president Haruo Yamaguchi seems prepared to discuss separation of the small mobile telecommunications sector but is otherwise strongly opposed to the plan. He says a break-up would interfere with NTT's plans to introduce a new nationwide telecommunications network, ISDN, and would result in reduction of NTT's research and development activities.

The powerful federation of Economic Organizations (Keidanren) has called for a three-year delay in making any decision on the future of NTT. And the opposition Japan Socialist Party (JSP) is also against the plan. But the most powerful opponent of the plan is the Ministry of Finance.

The ministry has been selling off government-held shares of NTT since the company was privatized in 1985 . The share sales are an important source of government revenue and the government still holds 5 million shares worth over $¥ 6$ million million ( $\$ 40,000$ million) at the current market price ( $¥ 1.23$ million). But the share price has been plummeting and the ministry fears that break-up will cause a further fall in value. Nevertheless, the Ministry of Post and Telecommunications seems determined to adopt the council's recommendations this month, and a fight over the future of NTT seems inevitable.

David Swinbanks 